Dr. Charles Palache, professor of petrography, Harvard University.

Mr. Louis V. Pirsson, professor of petrography, Yale University.

Dr. Henry S. Washington, petrographer.

Professor L. von Jaczewski, professor of mineralogy and geology at the University of Ekaterinoslav, St. Petersburg.

Herrn Geheimrath Dr. A. B. Meyer, director Königliches Zoologisches und AnthropologischEthnographisches Museum, Dresden.

Herrn Dr. Max Bauer, director Mineralogisches Institut der Königliches Universität, Marburg (Hessen).

Mr. Robinson, artist.

Dr. Thomas Wilson, late curator, Division of Prehistoric Archeology, Smithsonian Institution, U. S. National Museum, Washington.

Dr. Joseph Edkins, of Shanghai.

Professor A. Damour, of Paris.

Dr. Ludwig Leiner, curator of Rosegarten $\mathrm{Mu}$ seum, Constance.

Mrs. Zella Nuttall, Pèbody Museum, Cambridge, Mass.

Miss Eliza Scidmore.

Dr. F. Berwerth, Mineralogisches Abtheilung, Hof Museum, Vienna.

Professor Ernst Weinschenk, professor of petrography at the Mineralogisches Institut, Munich.

The Field Columbian Museum, Chicago.

The Smithsonian Institution, Washington, D. C. The Museum of Natural History, New York.

The following French etchers were represented: Sulpis, Guerard, Richard, Piquet, Le Rat, Coutry and a number of plates by Smillie of the United States.

The lithographs are by Prang \& Co., and Forbes \& Co., of Boston.

Name of maker of paper, the finest handmade linen paper, especially made by the L. L. Brown Paper Co., Adams, Mass.

Name of printer, Theo. L. De Vinne \& Co., Lafayette Place, New York. It is the most important work that has ever come from the De Vinne press.

Name of binders, Stikeman \& Co., New York. Bound in full Levant with exquisite tooling. No hundred volumes have ever received such stately bindings of green Levant as was produced by Stikeman \& Co.
The tools for the decorations by George W. De Lacey.

A series (twelve full-page) of water-color sketches of all the processes of working jade in évery possible manner was made in China by Chinese artists.

The original lithographic color plates were laid out on the lines of "Gems and Precious Stones of North America.'

Among great illustrated books there are, Audubon's folio of birds, Svenegrodzkoi, 'Byzantine Animals,' published in Russia, Gould's 'Birds of Many Lands,' the great illustrated catalogue of Chinese porcelain of the Walters collection, issued by Mr. Henry Walters, the treasures of Tzarkoe Zelo, by the Russian governor, catalogue of the J. P. Morgan collection of Oriental porcelains. Magnificent as these all are, each in its own way, none of them possesses the great variety of artistic illustrations as does the great Heber R. Bishop catalogue.

This whole work, from its inception by $\mathrm{Mr}$. Bishop in 1886 to the final distribution of the volumes, has required about twenty years. It is a cause for much satisfaction that the enterprise has been so fully and successfully completed, along the lines which he laid down; but it is also a source of profound regret that he could not himself have lived to witness its final place.

This whole cost has been met by the liberality of Mr. Bishop's provision, carried out by the care and thoughtfulness of his three executors, Messrs. Moses Taylor, Frank C. Bishop and Alexander James Patterson.

I must here express my thanks and appreciation to Mr. Alexander James Patterson, who has been untiring in his zeal and carefulness throughout the entire carrying out of $\mathrm{Mr}$. Bishop's wishes, both written and unwritten, and to whose courtesy I am indebted for many of these facts, furnished me for the preparation of this article.

George Frederick Kunz.

THE ROCK OF THE PELÉE OBELISK AND THE CONDITION OF THE VOLCANO IN FEBRUARY, 1906.

The measure of doubt which has all along attached to the character and constitution of 
the rock-mass which built up the great Pelean monolith may probably now be considered removed. A period of many months' quietude into which the volcano has entered has also permitted of a closer approach to its center theater of activity than has hitherto been possible, and given access to parts the study of which can now be made directly rather than inferentially. The Pelée obelisk exists to-day only in its basal wreck, the jagged crest which still protrudes in a partially severed connection from the summit of the supporting dome, and in a wilderness of débris, composed of small and giant fragments, which covers much of the surface of the dome and fills in a considerable part of the circumvallating hollow (rainure) that separates the dome from the bounding wall of the ancient crater-basin. On the twenty-seventh of February of this year, following an unusually easy ascent of the volcano, I succeeded in gaining the floor of the old crater by climbing over the sharp arête of the northeast wall, and was soon among the boulder-masses of the destroyed obelisk. Fragments from two to three feet in diameter to others measuring ten, twenty or thirty feet, were everywhere, and they all showed practically the same construction. The rock is a compact, light-gray, and virtually holocrystalline hypersthene-andesite, devoid of vesicles or of any vesicular or obsidian-like structure, and having a fine-grained base. So far as an absolute reference is made possible, it seems to belong to Lacroix's type IV. (quartzitic andesites) of the ejected material from the volcano. ${ }^{1}$ Of course, it can be that in parts of the débris that are now covered up and no longer accessible fragments might occur that are more or less vesicular or scoriaceous in character, but in the very large number of blocks that were examined by me and my associate none having this character was detected.

Climbing over the boulders, somewhat in the form of stepping-stones, we gained a con-

${ }^{1}$ Professor L. V. Pirsson, of the Sheffield Scientific School, has kindly looked over some of the material for me. A more detailed study of the rock will be made at a future day. siderable height on the dome itself, passing a number of fumarolic vents from which the disengagement of vapor was still fairly active. Clumps of diminutive fern are now beginning to grow about these. The partially free flows of lava which enter as ribbed-structures into the mass of the dome appear likewise as compact andesite. I may remark here that the sound of the falling masses which has been likened to that produced by the breaking of glass and porcelain, and from which a possible vesicular structure was inferred, is that given out by the compact andesite.

As regards the origin and method of formation of the extruded andesite monolith, while recognizing that the criteria for distinguishing between a newly-made rock and one of ancient date are not necessarily apparent or of a nature to yield positive evidence, I have no reason to change the view that I have elsewhere expressed ${ }^{2}$ that it represented an ancient plug or core that had been lifted up in the manner of the giant granite mass (and domite?) of the Puy Chopine, of the Auvergne.

For the benefit of vulcanologists and seismologists who are preparing catalogues of eruptions and general volcanic disturbances it may be proper to add that, despite reports to the contrary, Pelée had not been in activity in the early part of this year, and it took no part, so far as outward appearances were concerned, in the events which were associated with the earthquakes in St. Lucia and Martinique on February 16. The dome in its upper parts is still quietly disengaging vapor.

\section{ANGelo HeILPRin.}

\section{THE COMMISSION FOR BRAIN INVESTI- GATION.}

ON May 27 the third meeting of the Commission for Brain Investigation was held at Vienna. This commission is one of several established by the International Association of Academies and has for its purpose the advancement of neurological research, especially by the establishment of central institutes in the various countries, as well as by

'In ScIence and in my 'Tower of Pelee.' 